\title{
Transepithelial gllucose transport in the small intestine
}

\author{
M. Pavić, M. Šperanda, H. Brzica, S. Milinković-Tur, M. Grčević, \\ I. Prakatur, I. Žura Žaja and M. Ljubojević
}

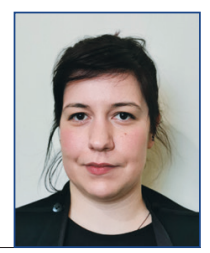

\section{Abstract}

The duodenum, jejunum and ileum are parts of the small intestine and the sites of the terminal stages of enzymatic digestion, and the majority of nutrient, electrolyte and water absorption. The apical, luminal membrane of the enterocyte is built of numerous microvilli that increase the absorptive surface of the cell. Carbohydrates, in the form of monosaccharides, oligosaccharides and especially polysaccharides, make up the largest quantitative and energetic part of the diet of most animals, including humans. Galactose, fructose and glucose, the final degradation products of polysaccharide and oligosaccharide enzymatic digestion, can be absorbed by enterocytes either by active transport or by facilitated diffusion. In the small intestine, the transepithelial transport of glucose, the most abundant monosaccharide after carbohydrate digestion and the main source of energy, is performed by a specific membrane transporter located in the brush border membrane of the enterocyte, the sodiumglucose cotransporter 1 (SGLT1). While

SGLT1 transports glucose across the brush border membrane, a specific basolateral membrane glucose transporter, the sodium-independent glucose transporter 2 (GLUT2), transfers glucose out of the enterocyte down the concentration gradient. The sodium-potassium pump (Na/KATPase), as a sodium and potassium ion transporter, is functionally closely related to the sodium-dependent SGLT1. Na/KATPase is responsible for maintaining the electrochemical gradient of sodium ions, as the driving force for glucose transport via SGLT1. Transepithelial transport of glucose in the small intestine and the differentiation of enterocytes occur relatively early during the foetal period, allowing glucose to be absorbed from ingested amniotic fluid. Nutrient transport is possible along the whole villus-crypt axis during intrauterine development, while transport shifts toward the villus tip in the mature small intestine. With maturation, glucose transport rates change not only across the villus-crypt axis, but also along the proximodistal axis in the

Mirela PAVIĆ*, DVM, PhD, Assistant Professor, (Corresponding author: e-mail: mpavic@vef.hr), Suzana MILINKOVIĆ-TUR, DVM, PhD, Full Professor, Ivona ŽURA ŽAJA, DVM, PhD, Assistant Professor, Faculty of Veterinary Medicine, University of Zagreb, Croatia; Marcela ŠPERANDA, DVM, PhD, Full Professor, Manuela GRČEVIĆ, Grad. Food Technol. Eng., PhD, Senior Expert Associate, Ivana PRAKATUR, Grad. Agr. Eng., PhD, Assistant Professor, Faculty of Agrobiotechnical Sciences Osijek, University of Josip Juraj Strossmayer Osijek, Croatia; Hrvoje BRZICA, DVM, PhD, Fidelta Ltd., Zagreb, Croatia; Marija LJUBOJEVIĆ, Grad. Mol. Biol. Eng., PhD, Senior Scientific Associate, Molecular Toxicology Unit, Institute for Medical Research and Occupational Health, Zagreb, Croatia 
small intestine. The glucose absorption rate shows differences between subunits of the small intestine depending on the age and type of ingested carbohydrates, where complex carbohydrates replace less complex carbohydrates or disaccharides.

Key words: glucose absorption; small intestine; SGLT1; GLUT2; Na/K-ATPase

\section{Introduction}

The small intestine (lat. intestinum tenue) of the digestive tract is divided, by length and structure, into three unequal units: duodenum, jejunum and ileum. Terminal stages of enzymatic digestion are completed and the greatest extent of nutrient, water and electrolyte absorption take part in the duodenum and proximal part of the jejunum. Due to its primary role, the absorption of nutrients, the small intestine mucosa is highly folded, multiplying its luminal surface several times to increase absorptive capacity. The luminal or absorptive surface of the small intestine is increased up to 600 times in humans by the presence of valves of Kerckring ( 3x increase), intestinal villi ( 10x increase) and microvilli ( $20 \mathrm{x}$ increase), compared to the surface of a simple cylindrical tube of the same length. The mucous membrane of the digestive system, aside being the main site of absorption, is also the first barrier for entry of both useful and harmful substances into the body, i.e. into the blood circulation. The intestinal barrier consists of a single layer of epithelial cells with a thin, underlying layer of loose connective tissue (lat. lamina propria) containing lymphatic and blood capillaries. Absorption of nutrients from the lumen of the digestive tract involves transport through the epithelial cell, i.e. transepithelial transport, more than through the lamina propria and the endothelium, i.e. the wall of the lymphatic or blood capillaries. The mucosa of the absorptive part of the digestive tract is made of several types of cells. The most abundant are the highly prismatic epithelial cells, enterocytes, arranged in a single layer, through which the processes of nutrient absorption in the digestive tract take place. There are numerous microvilli on the apical, luminal, part of the enterocytes, giving the apical cell membrane a brush-like appearance, and therefore, they have been called brush border membranes (Caspary, 1992; Desesso and Jacobson, 2001; Chichlowski and Hale, 2008).

\section{Carbohydrate digestion}

Carbohydrates, in the form of monosaccharides, oligosaccharides and especially polysaccharides, account for more than $50 \%$ of the daily caloric intake and thus make up the largest quantitative and energetic part of the diet of most animals, including humans (Caspary, 1992). It is thought that people with a modern dietary pattern, i.e. the Western diet, consume about one mole of glucose daily, or approximately 180 $\mathrm{g}$ glucose, which is absorbed together with approximately $46 \mathrm{~g}$ of sodium in the small intestine (Wright et al., 2007).

Before being absorbed in the small intestine, polysaccharides and oligosaccharides need to be broken down into monosaccharides by digestive enzymes. In some species, the enzymatic digestion of starch, the most prevalent polysaccharide in the diet of most domestic animals and humans, already begins in the oral cavity by salivary amylase, then continues in the lumen of the small intestine by pancreatic amylase and ends on the brush border 
membranes of enterocytes in the small intestine. The final degradation products of polysaccharides and oligosaccharides are monosaccharides - galactose, fructose and, dominantly, glucose, which can be absorbed by enterocytes either by active transport or facilitated diffusion. Glucose is the main source of energy and an important metabolic substrate for protein and lipid synthesis in mammalian cells. The breakdown of glucose in the process of glycolysis and the citric acid cycle releases energy in the form of adenosine triphosphate (ATP). Glucose is used as a substrate in the synthesis of glycerol to produce triglycerides and non-essential fatty acids. Large amounts of glucose are also used in the mammary gland to produce lactose during lactation (Wood and Trayhurn, 2003; Wright et al., 2003; Zhao and Keating, 2007; Boehlke et al., 2015).

The tissue glucose amount is largely dependent on the availability, digestion and absorption of carbohydrates in the small intestine (Zhao and Keating, 2007). In addition to absorption from digested food, the need for glucose is also enhanced by de novo synthesis of glucose from certain non-carbohydrate carbon precursors, i.e. gluconeogenesis, in the liver and kidneys. After absorption in the small intestine, a large part of fructose and almost all galactose are transformed into glucose in the liver and released back into the blood circulation. It is assumed that $95 \%$ of all circulating monosaccharides are glucose (Guyton and Hall, 2006).

Since glucose is hydrophilic, specific integrated transmembrane proteins, i.e. glucose transporters are required for transport through cell membranes. Glucose transport through enterocytes involves two steps - entry into the enterocyte across the brush border membrane and exit out of the enterocyte at the basolateral membrane (Miyamoto et al., 1992).

\section{The sodium-potassium pump (Na/K-ATPase)}

Although it was previously suggested that cellular membranes have transporters for sodium ions, Skou (1957) was the first to propose the existence of a common sodium and potassium ion transporter with energy consumption in the form of ATP. Transport of sodium ions through the enterocyte takes place either by joint transport with other molecules via the sodium-hydrogen exchanger 3 (NHE3, SLC9A3) through the brush border membrane, or by active transport against the concentration gradient on the basolateral membrane out of the cell via $\mathrm{Na} / \mathrm{K}$-ATPase (Coon et al., 2011; Rocafull at al., 2012).

$\mathrm{Na} / \mathrm{K}$-ATPase is a highly conserved transmembrane enzyme extremely important for maintaining cellular homeostasis. It is responsible for maintaining a low intracellular concentration of sodium ions and a high concentration of potassium ions, which is important for maintaining cell membrane potential and the electrochemical gradient for the transport of metabolites and nutrients across the cell membrane. $\mathrm{Na} / \mathrm{K}$-ATPase is also the only pathway in mammals for transporting sodium ions out of the cell under physiological conditions. Maintaining cell membrane potential is extremely important in excitable cells, such as muscle and nerve cells. In addition, $\mathrm{Na} / \mathrm{K}$-ATPase is also important for maintaining cell volume and osmotic pressure within the cell, and indirectly for cytoplasmic $\mathrm{pH}$ and calcium ion levels. The $\mathrm{Na} / \mathrm{K}$-ATPase needs energy in the form of cytosolic ATP for its work. Hydrolysis of one ATP molecule releases sufficient energy to transport three sodium ions out of the cell and two potassium ions into the cell (Rose and Valdes, 1994; Therien and Blostein, 2000; Yu, 2003). Due to its extreme importance, $\mathrm{Na} / \mathrm{K}$-ATPase can be found in almost all 
mammalian cells. However, depending on the metabolic activity of the cell itself, $\mathrm{Na} / \mathrm{K}$-ATPase expression varies on membranes. Thus, it has been observed that $\mathrm{Na} / \mathrm{K}$-ATPase expression is 160,000 times higher in nerve cells than in erythrocyte membranes (Köksoy, 2002).

As much as $95 \%$ of total cellular $\mathrm{Na} /$ $\mathrm{K}$-ATPase is thought to be located on the basolateral membranes of mammalian cells (Mircheff and Wright, 1976). Although it is generally reported that $\mathrm{Na}$ / $\mathrm{K}$-ATPase is located on the basolateral cell membranes, in fact it is primarily located on the lateral membranes of enterocytes. Such a location of $\mathrm{Na} / \mathrm{K}$ ATPase corresponds to the current knowledge of ion and water transport in enterocytes. Sodium ions exit into the intercellular spaces due to the location of $\mathrm{Na} / \mathrm{K}$-ATPase on the lateral membranes, thus increasing the osmotic pressure inside the intercellular spaces due to the slow passage of ions through the intercellular space towards the lamina propria. This increase of osmotic pressure in the intercellular space causes water to exit the enterocyte, which reduces osmotic pressure in the intercellular space, creating an isotonic solute that enters the lamina propria of the intestinal villi (Amerongen et al., 1989; Wright and Loo, 2000).

\section{The sodium-glucose cotransporter 1 (SGLT1)}

Crane, (1960) already observed that glucose transport in the small intestine is connected to the transport of sodium ions, while the first sodium-dependent glucose transporter, SGLT1, was identified in the rabbit jejunum only twenty years later (Peerce and Wright, 1984). The first successful isolation of cDNA encoding SGLT1 in the small intestine of rabbits was reported in 1987 (Hediger et al., 1987), and two years later in humans (Hediger et al., 1989).
The SLC5 gene family has 11 members in humans, nine of which have a known function and six of which are transporters. The roles of sodium-glucose cotransporter 4 (SGLT4, SLC5A8), primarily found in the small intestine, and sodium-glucose cotransporter 5 (SGLT5, SLC5A9), found only in the kidneys, are still unknown. SGLT1 (SLC5A1) is primarily located on the brush border membrane of mature enterocytes and in the S3 segment of proximal tubules in kidneys. Sodiumglucose cotransporter 2 (SGLT2, SLC5A2) is expressed only in the renal cortex on the brush border membranes of the S1 and S2 segments of proximal tubules where it reabsorbs glucose, up to $180 \mathrm{~g}$ daily in humans, from glomerular filtrate. Sodium-glucose cotransporter 3 (SGLT3, SLC5A4) is a glucose transporter found in the small intestine, kidneys and muscles with an extremely low affinity for glucose and its role as a transporter is negligible. SGLT3 is thought to function as a glucose sensor. Sodium-glucose cotransporter 6 (SGLT6, SLC5A10) is a widespread low affinity transporter for glucose and myoinositol, a precursor for the synthesis of phospholipids containing inositol. Sodium/myoinositol transporter (SMIT1, SLC5A3) is a transporter of sodium ions and myoinositol and can be found in the brain, heart, kidneys and lungs. Sodium/ iodide symporter (NIS, SLC5A5) is a sodium ion and iodine transporter located on the basal membranes of the thyroid gland, while the apical iodide transporter (AIT, SLC5A11) is located on the apical membranes. Sodiumdependent multivitamin transporter (SMVT, SLC5A6) is a widespread transporter of sodium ions and vitamins such as biotin (vitamin B7) and pantothenic acid (vitamin B5). The choline transporter (CHT, SLC5A7) is a transporter in the central nervous system where it transports choline 
through nerve cell membranes, where the neurotransmitter acetylcholine is synthesized from choline (Scheepers et al., 2004; Wright et al., 2007; Balen et al., 2008; Balon, 2012; Sabolić et al., 2012; Augustin and Mayoux, 2014).

SGLT1 has a binding site for both glucose and sodium ions, and the sodium concentration gradient is the driving force for glucose transport. Namely, the concentration of sodium ions is lower inside the cell than outside, therefore two sodium ions move down the concentration gradient into the cell via SGLT1 in co-transport with one molecule of glucose (Breves et al., 2007). The extracellular part of the free SGLT1 transporter first binds the two sodium ions, which change the transporter conformation allowing glucose to bind, while glucose is the first to be released into the cell after transmembrane transport (Thorsen et al., 2014). The passage of sodium ions and glucose induces the entry of water from the intestinal lumen through the enterocyte into circulation. Each molecule of absorbed glucose is accompanied by two sodium ions and 249 molecules of water (Wright and Loo, 2000; Loo et al., 2002). Na/K-ATPase, located on the basolateral membrane, maintains the concentration gradient of sodium ions and so contributes to glucose transport, even against the concentration gradient because of the increase in glucose concentration inside enterocytes. Inhibition of $\mathrm{Na} / \mathrm{K}$-ATPase results in inhibition of nutrient active transport, including glucose by SGLT1 (Caspary, 1992), whereas increased activity of $\mathrm{Na} / \mathrm{K}$ ATPase causes a decrease in intracellular sodium concentration, leading to an increase in the concentration gradient and increased glucose transport activity via SGLT1 (Alexander and Carey, 2001).

The gradient of SGLT1 expression in the small intestine in humans goes from the highest in the duodenum to lowest in the ileum (Chen et al., 2010). A simi- lar distribution pattern of SGLT1 expression was found in the small intestine of rats (Chang Wayhs et al., 2011) and mice (Yoshikawa et al., 2011). However, Balen et al. (2008) found that the highest SGLT1 expression in rats was in the jejunum, while the ileum and duodenum showed no differences in expression. In rabbits, the highest expression was observed in the jejunum (Takata et al., 1992), whereas no distribution difference was found in dogs or chickens (Garriga et al., 1999; Barfull et al., 2002; Batchelor et al., 2011). In their study on the distribution of SGLT1 expression along the small intestine in humans, mice and pigs, Van Der Wielen et al. (2014) confirmed that humans and mice have a similar distribution pattern, i.e. the highest expression in the duodenum, decreasing towards the ileum, while the highest expression in pigs was found in the jejunum.

The amount of carbohydrates in the diet affects the expression of SGLT1 in the small intestine. It is shown that a higher amount of carbohydrates in the diet increases the SGLT1 expression at the mRNA level in the small intestine of rats (Miyamoto et al., 1993). In pigs on the other hand, higher carbohydrates in the diet increased the expression of SGLT1 at mRNA and protein levels in the distal parts of the small intestine. The increased expression on the brush border membrane and a larger area of SGLT1 expression in the small intestine suggest a mechanism of small intestine adaptation to a greater amount of glucose (Moran et al., 2010). Slow digestible carbohydrates, composed of a greater proportion of hard-to-digest amylose, also increase SGLT1 expression at the mRNA level in the ileum of pigs, suggesting that the glucose concentration in the distal parts of the small intestine is relatively high due to the slower breakdown of carbohydrates, and therefore such carbohydrates are mostly absorbed in the ileum (Woodward et al., 2012). 


\section{Glucose transporter 2 (GLUT2)}

GLUT2 belongs to the glucose transporter (GLUT) family of 14 members of the SLC2 gene family. According to phylogenetic studies of sequence similarity, the sodium-independent GLUT family is divided into three classes. The first class includes glucose transporter 1 (GLUT1, SLC2A1), glucose transporter 2 (GLUT2, SLC2A2), glucose transporter 3 (GLUT3, SLC2A3), glucose transporter 4 (GLUT4, SLC2A4) and glucose transporter 14 (GLUT14, SLC2A14), which are also the most researched sodium-independent glucose transporters. The second class consists of GLUTs whose nomenclature does not fully correspond to the primary substrate they transport, fructose: glucose transporter 5 (GLUT5, SLC2A5), glucose transporter 7 (GLUT7, SLC2A7), glucose transporter 9 (GLUT9, SLC2A9) and glucose transporter 11 (GLUT11, SLC2A11). The third class consists of glucose transporter 6 (GLUT6, SLC2A6), glucose transporter 8 (GLUT8, SLC2A8), glucose transporter 10 (GLUT10, SLC2A10), glucose transporter 12 (GLUT12, SLC2A12) and hydrogen and myoinositol transporter (HMIT, SLC2A13). GLUT1, GLUT2, and GLUT3 are the only transporters of the GLUT family that are constantly present on cell membranes. GLUT1 is most prevalent in erythrocyte membranes and endothelial cells in the brain, while GLUT3 is located in tissues with high glucose requirements, such as the central nervous system and testicles. GLUT4, whose expression is regulated by insulin, transports glucose to muscle and adipose tissue. GLUT14 is found exclusively in the testicles. GLUT5 is well expressed in the brush border membrane of the proximal part of the small intestine where it transports fructose from the lumen into the enterocyte, while its role in the distal parts of the small intestine and in the colon is replaced by GLUT7. GLUT9, which also transports uric acid in addition to fructose, is mainly found in the kidneys and liver, while GLUT11 is found in the pancreas, kidneys and placenta. GLUT6 is a low-affinity glucose transporter found in the brain, spleen, and leukocytes. GLUT8, extremely important for the supply of sperm cells with glucose, is mainly expressed in the testicles and its expression is to be regulated by the sex hormones. GLUT10 is found mainly in the liver and pancreas, and GLUT12 in the heart and prostate. HMIT is exclusively expressed in the brain and is involved in the transport of myoinositol (Zhao et al., 1998; Joost et al., 2002; Li et al., 2004; Scheepers et al., 2004; Augustin and Mayoux, 2014; Long and Cheeseman, 2015).

GLUT2 is found in the liver, small intestine, kidney, islets of Langerhans in the pancreas and brain (Thorens et al., 1990; Cheeseman, 1993). In the kidneys and small intestine, GLUT2 is expressed on the basolateral cell membrane, where it is involved in the release of absorbed and reabsorbed glucose into the circulation (Kellett and Brot-Laroche, 2005). In hepatocytes, GLUT2 is responsible for releasing glucose produced by gluconeogenesis into the blood, while in the pancreatic $\beta$-cells and hypothalamus it acts as a glucose sensor, influencing the regulation of insulin secretion (Bady et al., 2006). The role of GLUT2 in the small intestine is to transport glucose, but also galactose and fructose, out of the cell through the basolateral membrane (Cheeseman, 1993).

GLUT2 is a low-affinity transporter (Km $\sim 17 \mathrm{mM}$ ) but therefore high in glucose transport capacity. Regardless of these characteristics, GLUT2 has the highest affinity for glucose within the GLUT family (Brown, 2000). In addition to glucose, GLUT2 also transports fructose $(\mathrm{Km} \sim 76 \mathrm{mM})$, galactose $(\mathrm{Km} \sim 92$ $\mathrm{mM})$ and mannose $(\mathrm{Km} \sim 125 \mathrm{mM})$, with 
the highest affinity for glucosamine (Km $\sim 0.8 \mathrm{mM}$ ) (Uldry et al., 2002; Zhao and Keating, 2007).

\section{Glucose absorption in the small intestine}

Transepithelial glucose transport starts with the activity of $\mathrm{Na} / \mathrm{K}$-ATPase, located on the basolateral membrane, which maintains the cellular concentration of sodium and potassium ions. $\mathrm{Na} / \mathrm{K}$ ATPase maintains the concentration gradient of sodium ions, primarily by active transport of three sodium ions out of the cell and two potassium ions into the cell, utilizing energy from the hydrolysis of one ATP molecule. The relatively lower sodium concentration in the cytoplasm of enterocytes compared to the intestinal lumen allows SGLT1, located on the brush border membrane, to transfer one molecule of glucose together with two sodium ions into the cell. This transfer of sodium ions down the concentration gradient is the driving force for the entry of glucose into the cell. Glucose transport via SGLT1 on the brush border membrane is secondarily active transport and as such does not utilize energy from the ATP molecule. Due to glucose absorption at the enterocyte brush border membrane via the SGLT1 transporter, glucose is concentrated in the cytoplasm of the apical part of the cell, which can either be metabolized in the enterocyte for its own use or stimulates passive diffusion via GLUT2 down the concentration gradient on the basolateral membranes of the enterocytes. Thus, glucose from enterocytes enters the intercellular fluid of the intercellular spaces just below the tight junctions (Thorens et al., 1990; Hwang et al., 1991; Kellett, 2001; Drozdowski and Thomson, 2006; Wright et al., 2007). The above described model of glucose transport through enterocytes is known as the "classic model of glucose absorption" (Figure 1).
During glucose absorption, the enterocyte loses about $30 \%$ of intracellular fluid into the intercellular space, causing the intercellular space to expand below the tight junctions, and therefore enterocytes take the form of a truncated cone with the base on the apical membrane and the tip on the basal membrane (Pappenheimer and Michel, 2003). Thus, the expanded intercellular space is able to receive larger quantities of absorbed substances, reducing the need to move toward the basal membrane and to pass eventually through the much less permeable membrane of the nucleus and mitochondria located closer to the basal membrane (Thorsen et al., 2014). Although it is commonly accepted that glucose exits enterocytes via GLUT2 on the basolateral membrane, Pappenheimer and Michel (2003) showed that GLUT2 is

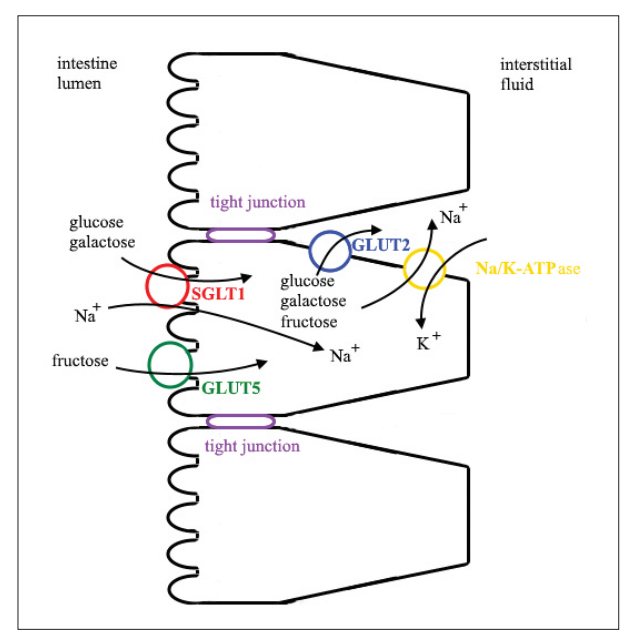

Figure 1. The classic model of glucose absorption in enterocytes. Glucose and galactose are transported through the brush border membrane of enterocytes together with two sodium ions via SGLT1. The concentration gradient of sodium ions, is maintained by the basolaterally located $\mathrm{Na} / \mathrm{K}$-ATPase. Fructose enters the enterocyte on the brush membrane by facilitated diffusion via GLUT5. Basolaterally located GLUT2 transports absorbed monosaccharides out of the cell by facilitated diffusion down the concentration gradient (Drozdowski and Thomson, 2006; Pavić, 2017) 
located mainly on the lateral portions of the basolateral enterocyte membrane, i.e. at the same site where sodium ions exit enterocytes into the intercellular space against the concentration gradient via $\mathrm{Na} / \mathrm{K}$-ATPase.

Monosaccharide absorption in the small intestine of omnivores is an efficient process that prevents unnecessary passage of glucose to the large intestine. Larger amounts of undigested carbohydrates in the large intestine can cause diarrhoea due to an increase in osmotic pressure within the intestinal lumen, as well as excessive bacterial growth (Svetina et al., 2013). Unabsorbed carbohydrates that reach the large intestine are subject to bacterial digestion by the action of their intracellular disaccharides or anaerobic fermentation, resulting in the production of short-chain fatty acids, hydrogen, carbon dioxide and methane. Short-chain fatty acids can be absorbed in the large intestine and thus become a source of energy (Caspary, 1992; Cheeseman, 2002).

In order to prevent the unnecessary loss of glucose, there are many theories about additional glucose transport on the brush border membrane of enterocytes, particularly in conditions of increased concentrations of glucose in the intestinal lumen, with two widely accepted theories. The first presumes that glucose passes by cells, i.e. paracellularly through tight junctions that are open, either by activation via SGLT1 or by an increase in solute concentration in the intestinal lumen, i.e. solvent drag (Madara and Pappenheimer, 1987; Pappenheimer and Reiss, 1987). The second theory, of more recent origin, is based on the assumption that GLUT2 can be transferred from intracellular stores to the brush border membrane via signalling mechanisms involving protein kinase C (PKC), triggered by the activation of SGLT1 on the enterocyte brush border membrane. The appearance of GLUT2, as a transport- er with less affinity but greater capacity to transport glucose in the brush border membrane, could explain the sudden increase in glucose transport at the brush border membrane under conditions of increased glucose concentration in the intestinal lumen (Kellett, 2001; Au et al., 2002; Helliwell et al., 2003).

Glucose transport through the brush border membrane by SGLT1 is well explained at lower glucose concentrations in the intestinal lumen $(\leq 10 \mathrm{mM})$. However, at higher glucose concentrations $(\geq 25 \mathrm{mM})$, e.g. immediately after a meal, the observed increased glucose absorption cannot be explained by transport solely via SGLT1. Increasing glucose concentration in the intestinal lumen to about $25 \mathrm{mM}$ is thought to equalize active and passive glucose transfer at the brush border membrane, whereas at higher glucose concentrations, passive transfer down the concentration gradient prevails (Naftalin, 2014). It has been observed that in addition to the usual location on the basolateral membranes, GLUT2 can also be found on the brush border membrane, due to the high glucose concentrations achieved in the intestinal lumen within minutes (Affleck et al., 2003). Recent findings propose that, due to high glucose concentration in the intestinal lumen and SGLT1 saturation, mechanisms activating PKC leading to translocation of GLUT2 to the brush border membrane are triggered, thereby enhancing glucose absorption down the concentration gradient (Kellett and Helliwell, 2000; Au et al., 2002; Helliwell et al., 2003; Kellett and Brot-Laroche, 2005; Boudry et al., 2007; Kellett et al., 2008; Zheng et al., 2012). The role of SGLT1 in regulating the activity and translocation of GLUT2 to the brush border membrane was further demonstrated in experiments on rats using the glycoside florizin, a specific SGLT1 inhibitor, which despite high intraluminal glucose concentration, 
prevented intestinal glucose transport via SGLT1 and consequently GLUT2 (Kellett, 2001).

Due to the prolonged high concentration of glucose in the small intestine lumen and therefore greater absorption, glucose concentration in the intercellular fluid is increased, thereby reducing the concentration gradient on the basolateral membrane of enterocytes and decreasing basolateral glucose transport out of the cell. This results in an increase of glucose concentration within the cell. If the increase in cellular glucose concentration exceeds the glucose concentration in the intestinal lumen, the direction of glucose transport via GLUT2 on the brush border membrane reverses. In this case, GLUT2 acts as a glucose shunt on the brush border membrane, preventing excessive glucose accumulation in the enterocyte cytoplasm. GLUT2 regulates the total net glucose entry from the intestinal lumen into the enterocyte, but also distributes the luminal glucose to the more distal parts of the small intestine, exposing larger areas to glucose (Naftalin, 2014).

In ruminants, most carbohydrates are digested to short-chain fatty acids by fermentation in the rumen, under the action of microorganisms, and therefore a very small amount of carbohydrates reaches the small intestine, resulting in significantly lower SGLT1 expression in the small intestine compared to omnivores (Zhao et al., 1998). However, ruminants have pronounced SGLT1 activity in the forestomaches in order to absorb the monosaccharides that are easily fermented and can cause acid indigestion, i.e. ruminal acidosis (Aschenbach et al., 2002).

\section{Glucose absorption during intrauterine development}

Embryonic, foetal and post-natal development of the digestive system includes growth, of total tissue mass, size and number of cells, but also maturation in the form of structural and functional changes. The foetal development and maturity stage of the human digestive system at birth are similar to precocial species, i.e. species with longer gestation and therefore born with a more mature digestive system, such as pigs, than to altricial species with relatively short gestation and immature digestive system at birth, e.g. mice and rats. Although the activity of certain nutrient transporters is already recorded during foetal development, there are differences in the appearance period and expression of certain transporters. In precocial species, including humans, the transporters are activated earlier, allowing the foetus to absorb carbohydrates, amino acids and proteins from ingested amniotic fluid (Pácha, 2000; Guilloteau et al., 2010; Krstanović et al., 2013).

Active transport of nutrients in the small intestine in pigs and humans appears relatively early during the foetal period, together with enterocyte differentiation. Transport of nutrients is possible along the whole villus-crypt axis during intrauterine development, while during maturation, transport activity shifts toward the villus tip in the small intestine (Guilloteau et al., 2010). Disaccharidase activity in brush border membranes and active glucose transport in enterocytes appear in the human embryonic small intestine between week 10 and 11 of pregnancy, or when $25 \%$ of pregnancy has passed (Lindberg, 1966; Levin et al., 1968), while the glucose absorption gradient from the duodenum to the ileum is already established between weeks 17 (40\% of pregnancy) and 30 (75\% of pregnancy) of pregnancy (Malo and Berteloot, 1987). Buddington and Malo (1996) observed a similar pattern for the activity of glucose transporters in the foetal small intestine of pigs, where they found that lactase activity, one of the 
disaccharidases, and glucose transporters was already present in week 7 of gestation (43\% gestation) with a peak of transport activity development in week 10 of gestation (61\% of gestation). The glucose absorption gradient from the duodenum to the ileum was established by week 12 of gestation ( $74 \%$ of gestation). Lactase activity in piglets remains stable for the first 10 days post partum, after which its activity begins to decline. During this period, invertase and maltase activity was observed, and became the dominant disaccharidases in the small intestine of pigs (Smith, 1988).

Enterocytes are formed in intestinal crypts from multipotent intestinal stem cells (ISCs). Throughout maturation, enterocytes migrate toward the apical part of the intestinal villi, during which they differentiate and acquire their function by activation of disaccharidases in the brush border membrane and by activation of membrane transporters. When they finally reach the villus tip, they are shed into the intestinal lumen. This restoration process takes $2-3$ days in rodents, 3-4 days in sheep and 5-6 days in humans. Therefore, enterocytes of all stages of maturity can be physiologically found along the intestinal villi. As the enterocyte matures, the disaccharidase activity increases in the brush border membranes (Buddington and Diamond, 1989; Shirazi-Beechey, 1995). Ferraris and Diamond (1993) found that changes in the number of SGLT1 transporters in the intestinal villi, as an adaptation to diet, change with the sudden increase or decrease in carbohydrate content. These changes begin in crypts where immature enterocytes are found, and a change in glucose transport observed only after a certain time. The distribution of $\mathrm{Na} / \mathrm{K}$ ATPase along the intestinal villi indicates a stronger expression in the apical part where mature enterocytes are located (Rowling and Sepulveda, 1984; Wild and Murray, 1992).
Before weaning in piglets, glucose transport decreases from the duodenum to the ileum, where it is as much as 4.5 times lower than in the duodenum. Nevertheless, glucose transport rates are highest in the jejunum, then in the ileum and duodenum after weaning. This change in the distribution of glucose transport rates is hypothesized to be due to altered diet after weaning. Hence, lactose as a carbohydrate source is replaced by more complex carbohydrates that require hydrolytic enzymes in the intestinal lumen, but also enzymes located in the brush border membrane that catalyse carbohydrates to monosaccharides (Puchal and Buddington, 1992; Vega et al., 1992).

\section{Conclusions}

This review outlines the current knowledge about glucose transepithelial transport and intrauterine development of transporters involved in glucose absorption in the small intestine, in the context of a comparative view of transporter physiology. Transporters involved in glucose transepithelial transport in the small intestine are key regulators of glucose use, glucose storage and hormonal control through glucose sensing. Although the mechanisms of $\mathrm{Na} / \mathrm{K}-\mathrm{ATPa} e$, SGLT1 and GLUT2 are intensively investigated, much remains unknown about substrate specificity, physiological and pathophysiological function, and gene regulatory mechanisms.

\section{References}

1. AFFLECK, J. A., P. A. HELLIWELL and G. L. KELLETT (2003): Immunocytochemical detection of GLUT2 at the rat intestinal brush-border membrane. J. Histochem. Cytochem. 51, 1567-1574.

2. ALEXANDER, A. N. and H. V. CAREY (2001): Involvement of PI 3-kinase in IGF-I stimulation of jejunal $\mathrm{Na}+-\mathrm{K}+$-ATPase activity and nutrient absorption. Am. J. Physiol. Gastrointest. Liver Physiol. 280, 222-228. 
3. AMERONGEN, H. M., J. A. MACK, J. M. WILSON and M. R. NEUTRA (1989): Membrane Domains of Intestinal Epithelial Cells: Distribution of $\mathrm{Na}+, \mathrm{K}+-\mathrm{ATPa} e$ and the Membrane Skeleton in Adult Rat Intestine during Fetal Development and after Epithelial Isolation. J. Cell Biol. 109, 2129-2138.

4. ASCHENBACH, J. R., T. BORAU and G. GÄBEL (2002): Sodium glucose-linked transport in the ruminal epithelium of fallow deer - comparison to sheep. J. Comp. Physiol. B. 172, 561-567.

5. AU, A., A. GUPTA, P. SCHEMBRI and C. I. CHEESEMAN (2002): Rapid insertion of GLUT2 into the rat jejunal brush-border membrane promoted by glucagon-like peptide 2 . Biochem. J. 367, 247-254.

6. AUGUSTIN, R. and E. MAYOUX (2014): Mammalian Sugar Transporters. In: Glucose Homeostasis. Ed. Szablewski, L. InTech, Rijeka, Croatia, pp. 3-36.

7. BADY, I., N. MARTY, M. DALLAPORTA, M. EMERY, J. GYGER, D. TARUSSIO, M. FORETZ and B. THORENS (2006): Evidence From Glut2Null Mice That Glucose Is A Critical Physiological Regulator Of Feeding. Diabetes 55, 988-995.

8. BALEN, D., M. LJUBOJEVIĆ, D. BRELJAK, H BRZICA, V. ŽLENDER, H. KOEPSELL and I. SABOLIĆ (2008). Revised immunolocalization of the Na+-D-glucose cotransporter SGLT1 in rat organs with an improved antibody. Am. J. Physiol. Cell. Physiol. 295, 475-489.

9. BALON, T. W. (2012): SGLT and GLUT: are they teammates? Focus on "Mouse SGLT3a generates proton-activated currents but does not transport sugar." Am. J. Physiol. Cell. Physiol. 302, C1071-C1072.

10. BARFULL, A., C. GARRIGA, A. TAULER and J. M. PLANAS (2002): Regulation of SGLT1 expression in response to Na+ intake. Am. J. Physiol. Regul. Integr. Comp. Physiol. 282, R738R743.

11. BATCHELOR, D. J., M. AL-RAMMAHI, A. W. MORAN, J. G. BRAND, X. LI, M. HASKINS, A. J. GERMAN and S. P. SHIRAZI-BEECHEY (2011): Sodium/glucose cotransporter-1, sweet receptor, and disaccharidase expression in the intestine of the domestic dog and cat: two species of different dietary habit. Am. J. Physiol. Regul. Integr. Comp. Physiol. 300, R67-R75.

12. BOEHLKE, C., O. ZIERAU and C. HANNIG (2015): Salivary amylase - the enzyme of unspecialized euryphagous animals. Arch. Oral Biol. 60, 11621176.

13. BOUDRY, G., C. I. CHEESEMAN and M. H. PERDUE (2007): Psychological stress impairs $\mathrm{Na}+$ dependent glucose absorption and increases GLUT2 expression in the rat jejunal brush-border membrane. Am. J. Physiol. Regul. Integr. Comp. Physiol. 292, R862-R867.

14. BREVES, G., J. KOCK and B. SCHRÖDER (2007): Transport of nutrients and electrolytes across the intestinal wall in pigs. Livest. Sci. 109, 4-13.
15. BROWN, G. K. (2000): Glucose transporters: Structure, function and consequences of deficiency. J. Inherit. Metab. Dis. 23, 237-246.

16. BUDDINGTON, R. K. and J. M. DIAMOND (1989): Ontogenetic development of intestinal nutrient transporters. Annu. Rev. Physiol. 51, 601-619.

17. BUDDINGTON, R. K. and C. MALO (1996): Intestinal brush-border membrane enzyme activities and transport functions during prenatal development of pigs. J. Pediatr. Gastroenterol. Nutr. 23, 51-64.

18. CASPARY, W. (1992): Physiology and pathophysiology of intestinal absorption. Am. J. Clin. Nutr. 55, 299S-308S.

19. CHANG WAYHS, M. L., M. B. DE MORAIS, U. F. MACHADO, S. M. NASSAR, U. F. NETO and O. M. SILVÉRIO AMÂNCIO (2011): Transepithelial transport of glucose and mRNA of glucose transporters in the small intestine of rats with irondeficiency anemia. Nutrition 27, 111-115.

20. CHEESEMAN, C. I. (1993): GLUT2 is the transporter for fructose across the rat intestinal basolateral membrane. Gastroenterology 105, 1050-1056.

21. CHEESEMAN, C. I. (2002): Intestinal hexose absorption: transcellular or paracellular fluxes. J. Physiol. 544, 336-336.

22. CHEN, J., S. WILLIAMS, S. HO, H. LORAINE, D. HAGAN, J. M. WHALEY and J. N. FEDER (2010): Quantitative PCR tissue expression profiling of the human SGLT2 gene and related family members. Diabetes Ther. 1, 57-92.

23. CHICHLOWSKI M. and L. P. HALE (2008): Bacterial-mucosal interactions in inflammatory bowel disease: an alliance gone bad. Am. J. Physiol. Gastrointest. Liver Physiol. 295, 6, G1139-G1149.

24. COON, S., R. KEKUDA, P. SAHA, U. SUNDARAM and W. VIRGINIA (2011): Reciprocal regulation of the primary sodium absorptive pathways in rat intestinal epithelial cells. Am. J. Physiol. Cell. Physiol. 300, C496-C505.

25. CRANE, R. K. (1960): Intestinal Absorption of Sugars. Physiol. Rev. 40, 789-825.

26. DESESSO, J. M. and C. F. JACOBSON (2001): Anatomical and physiological parameters affecting gastrointestinal absorption in humans and rats. Food Chem. Toxicol. 39, 209-228.

27. DROZDOWSKI, L. and A. THOMSON (2006): Intestinal sugar transport. World J. Gastroenterol. $12,1657-1670$.

28. FERRARIS, R. P. and J. M. DIAMOND (1993): Crypt/villus site of substrate-dependent regulation of mouse intestinal glucose transporters. Proc. Natl. Acad. Sci. USA, 90, 5868-5872.

29. GARRIGA, C., N. ROVIRA, M. MORETO and J. M. PLANAS (1999): Expression of Na+-Dglucose cotransporter in brush-border membrane of the chicken intestine Am. J. Physiol. Regul. Integr. Comp. Physiol. 276, R627-R631

30. GUILLOTEAU, P., R. ZABIELSKI, H. M. HAMMON and C. C. METGES (2010): Nutritional programming of gastrointestinal tract development. 
Is the pig a good model for man? Nutr. Res. Rev. 23, 4-22.

31. GUYTON, A. C. and J. E. HALL (2006): Textbook of Medical Physiology. $11^{\text {th }}$ edition. Elsevier Saunders, Philadelphia (PA), USA.

32. HEDIGER, M. A, M. J. COADY, T. S. IKEDA and E. M. WRIGHT (1987): Expression cloning and cDNA sequencing of the $\mathrm{Na}+$ glucose co-transporter. Nature 330, 379-381.

33. HEDIGER, M. A., E. TURK and E. M. WRIGHT (1989): Homology of the human intestinal $\mathrm{Na}+$ glucose and Escherichia coli $\mathrm{Na}+$ /proline cotransporters. Proc. Natl. Acad. Sci. USA 86, 57485752.

34. HELLIWELL, P. A., M. G. RUMSBY and G. L. KELLETT (2003): Intestinal Sugar Absorption Is Regulated by Phosphorylation and Turnover of Protein Kinase C BII Mediated by Phosphatidylinositol 3-Kinase- and Mammalian Target of Rapamycin-dependent Pathways. J. Biol. Chem. 278, 28644-28650.

35. HWANG, E. S., B. A. HIRAYAMA and E. M. WRIGHT (1991): Distribution of the SGLT1 Na+ glucose cotransporter and mRNA along the cryptvillus axis of rabbit small intestine. Biochem. Biophys. Res. Commun. 181, 1208-1217.

36. JOOST, H. G., G. I. BELL, J. D. BEST, M. J. BIRNBAUM, M. J. CHARRON, Y. T. CHEN, H. DOEGE, D. E. JAMES, H. F. LODISH, K. H. MOLEY, M. MUECKLER, S. ROGERS, A. SCHÜRMANN, S. SEINO and B. THORENS (2002): Nomenclature of the GLUT/SLC2A family of sugar/polyol transport facilitators. Am. J. Physiol. Endocrinol. Metab. 282, E974-E976.

37. KELLETT, G. L. and P. A. HELLIWELL (2000): The diffusive component of intestinal glucose absorption is mediated by the glucose-induced recruitment of GLUT2 to the brush-border membrane. Biochem. J. 350, 155-162.

38. KELLETT, G. L. (2001): The facilitated component of intestinal glucose absorption. J. Physiol. 531, 585595.

39. KELLETT, G. L. and E. BROT-LAROCHE (2005): Apical GLUT2 - a major pathway of intestinal sugar absorption. Diabetes 54, 3056-3062.

40. KELLETT, G. L., E. BROT-LAROCHE, O. J. MACE and A. LETURQUE (2008): Sugar absorption in the intestine: the role of GLUT2. Ann. Rev. Nutr. 28, 35-54.

41. KÖKSOY, A. A. (2002): Na+, K+-ATPase: a review. J. Ankara Med. Sch. 24, 73-82.

42. KRSTANOVIĆ, J., M. DOMAĆINOVIĆ, M. PAVIĆ, M. ĐIDARA and M. ŠPERANDA (2013): Perinatalni razvoj probavnog sustava svinje. Poljoprivreda 19, 59-64.

43. LEVIN, R. J., O. KOLDOVSKÝ, J. HOSKOVÁ, V. JIRSOVÁ and J. UHER (1968): Electrical activity across human foetal small intestine associated with absorption processes. Gut 9, 206213.

44. LI, Q., A. MANOLESCU, M. RITZEL, S. YAO, M. SLUGOSKI, J. D. YOUNG, X. Z. CHEN and C.
I. CHEESEMAN (2004): Cloning and functional characterization of the human GLUT7 isoform SLC2A7 from the small intestine. Am. J. Physiol. Gastrointest. Liver Physiol. 287, G236-G242.

45. LINDBERG, T. (1966). Intestinal dipeptidases: characterization, development and distribution of intestinal dipeptidases of the human foetus. Clin. Sci. 30, 505-515.

46. LONG, W. and C. I. CHEESEMAN (2015): Structure of, and functional insight into the GLUT family of membrane transporters. Cell Health Cytoskelet. 2015, 167-183.

47. LOO, D. D. F., E. M. WRIGHT and T. ZEUTHEN (2002): Water pumps. J. Physiol. 542, 53-60.

48. MADARA, J. L. and J. R. PAPPENHEIMER (1987): Structural basis for physiological regulation of paracellular pathways in intestinal epithelia. J. Membr. Biol. 100, 149-164.

49. MALO, C. and A. BERTELOOT (1987): Proximodistal gradient of $\mathrm{Na}+$-dependent D-glucose transport activity in the brush border membrane vesicles from the human fetal small intestine. FEBS Lett. 220, 201-205.

50. MIRCHEFF, A K. and E. M. WRIGHT (1976): Analytical isolation of plasma membranes of intestinal epithelial cells: identification of $\mathrm{Na}$, $\mathrm{K}$-ATPase rich membranes and the distribution of enzyme activities. J. Membr. Biol. 28, 309-333.

51. MIYAMOTO, K., T. TAKAGI, T. FUJII, T. MATSUBARA, K. HASE,Y. TAKETANI, T. OKA, H. MINAMI and Y. NAKABOU (1992): Role of liver-type glucose transporter (GLUT2) in transport across the basolateral membrane in rat jejunum. FEBS Lett. 314, 466-470.

52. MIYAMOTO, K., K. HASE, T. TAKAGI, T. FUJII, Y. TAKETANI, H. MINAMI, T. OKA and Y. NAKABOU (1993): Differential responses of intestinal glucose transporter mRNA transcripts to levels of dietary sugars. Biochem. J. 295, 211-215.

53. MORAN, A. W., M. A. AL-RAMMAHI, D. K. ARORA, D. J. BATCHELOR, E. A. COULTER, C. IONESCU, D. BRAVO and S. P. SHIRAZIBEECHEY (2010): Expression of Na+/glucose cotransporter 1 (SGLT1) in the intestine of piglets weaned to different concentrations of dietary carbohydrate. Br. J. Nutr. 104, 647-55.

54. NAFTALIN, R. J. (2014): Does apical membrane GLUT2 have a role in intestinal glucose uptake? F1000Res. 3, 1-33.

55. PÁCHA, J. (2000): Development of intestinal transport function in mammals. Physiol. Rev. 80, 1633-1667.

56. PAPPENHEIMER, J. R. and K. Z. REISS (1987): Contribution of solvent drag through intercellular junctions to absorption of nutrients by the small intestine of the rat. J. Membr. Biol. 100, 123-136.

57. PAPPENHEIMER, J. R. and C. C. MICHEL (2003): Role of villus microcirculation in intestinal absorption of glucose: coupling of epithelial with endothelial transport. J. Physiol. 553, 561574. 
58. PAVIĆ, M. (2017): Influence of gender and castration on the expression and distribution of transporters involved in transepithelial glucose transport in porcine small intestine. Dissertation. Faculty of Veterinary Medicine, University of Zagreb. (In Croatian).

59. PEERCE, B. E. and E. M. WRIGHT (1984): Conformational changes in the intestinal brush border sodium- glucose cotransporter labeled with fluorescein isothiocyanate. Proc. Natl. Acad. Sci. USA, 81, 2223-2226.

60. PUCHAL, A. A. and R. K. BUDDINGTON (1992): Postnatal development of monosaccharide transport in pig intestine. Am. J. Physiol. Gastrointest. Liver Physiol. 262, G895-G902.

61. ROCAFULL, M. A., L. E. THOMAS and J. R. DEL CASTILLO (2012): The second sodium pump: from the function to the gene. Pflugers Arch. 463, 755777.

62. ROSE, A. M. and R. VALDES (1994): Understanding the sodium pump and its relevance to disease. Clin. Chem. 40, 1674-1685.

63. ROWLING, P. J. E. and F. V. SEPULVEDA (1984): The distribution of $(\mathrm{Na}++\mathrm{K}+)$-ATPase along the villus crypt-axis in the rabbit small intestine. Biochim. Biophys. Acta Biomembranes 771, 35-41.

64. SABOLIĆ, I., I. VRHOVAC, D. B. EROR, M. GERASIMOVA, M. ROSE, D. BRELJAK, M. LJUBOJEVIĆ, H. BRZICA, A. SEBASTIANI, S. C. THAL, C. SAUVANT, H. KIPP, V. VALLON and H. KOEPSELL (2012): Expression of Na+-D-glucose cotransporter SGLT2 in rodents is kidney-specific and exhibits sex and species differences. Am. J. Physiol. Cell Physiol. 302, C1174-C1188.

65. SCHEEPERS, A., H. G. JOOST and A. SCHÜRMANN (2004): The glucose transporter families SGLT and GLUT: molecular basis of normal and aberrant function. JPEN J. Parenter. Enteral Nutr. 28, 364-371.

66. SHIRAZI-BEECHEY, S. P. (1995): Molecular Biology of Intestinal Glucose Transport. Nutr. Res. Rev. 8, 27-41.

67. SKOU, J. C. (1957): The influence of some cations on an adenosine triphosphatase from peripheral nerves. Biochim. Biophys. Acta 23, 394-401.

68. SMITH, M. W. (1988): Postnatal development of transport function in the pig intestine. Comp. Biochem. Physiol. A Physiol. 90, 577-582.

69. SVETINA, A., M. SAMARDŽIJA, D. ĐURIČIĆ i LJ. BEDRICA (2013): Proljev neonatalne teladi u intenzivnom uzgoju. Vet. stn. 44, 205-212.

70. TAKATA, K., T. KASAHARA, M. KASAHARA, O. EZAKI and H. HIRANO (1992): Immunohistochemical localization of $\mathrm{Na}^{+}$ dependent glucose transporter in rat jejunum. Cell Tissue Res. 267, 3-9.

71. THERIEN, A G. and R. BLOSTEIN (2000): Mechanisms of sodium pump regulation. Am. J. Physiol. Cell Physiol. 279, C541-C566.

72. THORENS, B., Z. Q. CHENG, D. BROWN and H. F. LODISH (1990): Liver glucose transporter: a basolateral protein in hepatocytes and intestine and kidney cells. Am. J. Physiol. Cell Physiol. 259, C279-C285.

73. THORSEN, K., T. DRENGSTIG and P. RUOFF (2014): Transepithelial glucose transport and $\mathrm{Na}+/$ $\mathrm{K}+$ homeostasis in enterocytes: an integrative model. Am. J. Physiol. Cell Physiol. 307, C320-C337.

74. ULDRY, M., M. IBBERSON, M. HOSOKAWA and B. THORENS (2002): GLUT2 is a high affinity glucosamine transporter. FEBS Lett. 524, 199-203.

75. VAN DER WIELEN, N., M. VAN AVESAAT, N. J. W. DE WIT, J. T. W. E. VOGELS, F. TROOST, A. MASCLEE, S. J. KOOPMANS, J. VAN DER MEULEN, M. V. BOEKSCHOTEN, M. MÜLLER, H. F. J. HENDRIKS, R. F. WITKAMP and J. MEIJERINK (2014): Cross-Species Comparison of Genes Related to Nutrient Sensing Mechanisms Expressed Along the Intestine. PloS ONE, 9, e107531.

76. VEGA, Y. M., A. A. PUCHAL and R. K. BUDDINGTON (1992): Intestinal Amino Acid and Monosaccharide Transport in Suckling Pigs Fed Milk Replacers with Different Sources of Carbohydrate. J. Nutr. 122, 2430-2439.

77. WILD, G. E. and D. MURRAY (1992): Alterations in quantitative distribution of Na,K-ATPase activity along crypt-villus axis in animal model of malabsorption characterized by hyperproliferative crypt cytokinetics. Dig. Dis. Sci. 37, 417-425.

78. WOOD, I. S. and P. TRAYHURN (2003): Glucose transporters (GLUT and SGLT): expanded families of sugar transport proteins. Br. J. Nutr. 89, 3-9

79. WOODWARD, A. D., P. R. REGMI, M. G. GÄNZLE, T. A. T. G. VAN KEMPEN and R. T. ZIJLSTRA (2012): Slowly digestible starch influences mRNA abundance of glucose and shortchain fatty acid transporters in the porcine distal intestinal tract. J. Anim. Sci. 90, 80-82.

80. WRIGHT, E. M. and D. D. F. LOO (2000): Coupling between $\mathrm{Na}+$, Sugar, and Water Transport across the Intestine. Ann. N. Y. Acad. Sci. 915, 54-66.

81. WRIGHT, E. M., M. G. MARTÍN and E. TURK (2003). Intestinal absorption in health and disease - sugars. Best Pract. Res. Clin. Gastroenterol. 17, 943-956.

82. WRIGHT, E. M., B. A. HIRAYAMA and D. D. F. LOO (2007): Active sugar transport in health and disease. J. Intern. Med. 261, 32-43.

83. YOSHIKAWA, T., R. INOUE, M. MATSUMOTO, T. YAJIMA, K. USHIDA and T. IWANAGA (2011): Comparative expression of hexose transporters (SGLT1, GLUT1, GLUT2 and GLUT5) throughout the mouse gastrointestinal tract. Histochem. Cell Biol. 135, 183-194.

84. YU, S. P. (2003). Na+, K+-ATPase: The new face of an old player in pathogenesis and apoptotic/hybrid cell death. Biochem. Pharmacol. 66, 1601-1609.

85. ZHAO, F. Q., E. K. OKINE, C. I. CHEESEMAN, S. P. SHIRAZI-BEECHEY and J. J. KENNELLY (1998): Glucose transporter gene expression in lactating bovine gastrointestinal tract. J. Anim. Sci. 76, 29212929. doi: $10.2527 / 1998.76112921 x$ 
86. ZHAO, F. Q. and A. F. KEATING (2007): Functional Properties and Genomics of Glucose Transporters. Curr. Genomics, 8, 113-128.
87. ZHENG, Y., J.S.SCOW, J. A. DUENES and M. G.SARR (2012): Mechanisms of Glucose Uptake in Intestinal Cell Lines: Role of GLUT2. Surgery 151, 13-25.

\section{Prijenos glukoze kroz epitel tankoga crijeva}

Dr. sc. Mirela PAVIĆ, dr. med. vet., docentica, dr. sc. Suzana MILINKOVIĆ-TUR, dr. med. vet., redovita profesorica, Ivona ŽURA ŽAJA, dr. med. vet., docentica, Veterinarski fakultet Sveučilišta u Zagrebu, Zagreb, Hrvatska; dr. sc Marcela ŠPERANDA, dr. med. vet., redovita profesorica, dr. sc. Manuela GRČEVIĆ, dipl. ing. prehr. tehnol., viša stručna suradnica, dr. sc. Ivana PRAKATUR, dipl. ing. agr., docentica, Fakultet agrobiotehničkih znanosti Osijek, Sveučilište Josip Juraj Strossmayer Osijek, Hrvatska; dr. sc. Hrvoje BRZICA, dr. med. vet., Fidelta Ltd., Zagreb, Hrvatska; dr. sc. Marija LJUBOJEVIĆ, dipl. ing. mol. biol., viša znanstvena suradnica, Jedinica za molekulsku toksikologiju, Institut za medicinska istraživanja i medicinu rada, Zagreb, Hrvatska

Duodenum, jejunum i ileum dijelovi su tankog crijeva gdje se dovršava enzimatska razgradnja i najveći opseg apsorpcije hranjivih tvari, elektrolita i vode. Apikalna, luminalna stanična membrana enterocita građena je od brojnih mikrovila koji povećavaju apsorpcijsku površinu stanice. Ugljikohidrati, u obliku monosaharida, oligosaharida i posebno polisaharida, čine najveći kvantitativni i energetski dio prehrane većine životinja, ali i ljudi. Galaktozu, fruktozu i glukozu, krajnje produkte enzimatske razgradnje polisaharida i oligosaharida, enterociti mogu apsorbirati aktivnim prijenosom ili olakšanom difuzijom. Transepitelni prijenos glukoze, najzastupljenijeg monosaharida nakon razgradnje ugljikohidrata i glavni izvor energija $u$ tankom se crijevu odvija pomoću specifičnog transmembranskog prijenosnika smještenog u četkastom porubu membrane enterocita, prijenosnika glukoze ovisnog o natriju 1 (engl. sodiumglucose cotransporter 1, SGLT1). Dok SGLT1 prenosi glukozu preko četkastog poruba membrane, specifični prijenosnik smješten na bazolateralnoj membrani, prijenosnik glukoze neovisan o natriju 2 (engl. glucose transporter 2, GLUT2), prenosi glukozu iz enterocita niz koncentracijski gradijent. Natrij-kalijeva pumpa (Na/K-ATPaza), kao prijenosnik iona natrija i kalija, funkcionalno je usko povezana sa SGLT1. Na/K-ATPaza odgovorna je za održavanje elektrokemijskog gradijenta natrijevih iona, koji je pokretačka sila prijenosa glukoze putem SGLT1 prijenosnika. Transepitelni prijenos glukoze $\mathrm{u}$ tankom crijevu pojavljuje se relativno rano tijekom fetalnog razdoblja, zajedno s diferencijacijom enterocita, što omogućava apsorpciju glukoze iz progutane amnionske tekućine. Prijenos hranjivih tvari moguć je tijekom intrauterinog razvoja duž cijele dužine crijevne resice, dok se $\mathrm{u}$ zrelom tankom crijevu prijenos hranjivih tvari pomiče prema vrhu crijevne resice. Sazrijevanjem tankog crijeva aktivnost prijenosnika ne mijenja se samo duž crijevne resice, nego i duž proksimo-distalne osi $\mathrm{u}$ tankom crijevu. Apsorpcija glukoze $\mathrm{u}$ pojedinim dijelovima tankog crijeva mijenja se ovisno o dobi i vrsti konzumiranih ugljikohidrata, pogotovo kada složeni ugljikohidrati zamjenjuju manje složene ugljikohidrate ili disaharide u prehrani.

Ključne riječi: apsorpcija glukoze, tanko crijevo, SGLT1, GLUT2, Na/K-ATPaza 